\title{
The nucleolonema of plant and animal cells : a comparison
}

\author{
Roger Deltour, Patrick Motte \\ Université de Liège, Service de Morphologie Végétale, Département de Botanique, Bât. B22, Sart Tilman, \\ B4000 Liège, Belgium \\ (Received 27 June 1989; accepted 5 December 1989)
}

\begin{abstract}
Summary - Depending on the author and the animal or plant origin of the material under study, the term "nucleolonema" is used in different contexts and thus indicates nucleolar ultrastructures that are different. In this paper, we attempt to clarify this state of affairs and to propose a definition for the plant cell nucleolonema
\end{abstract}

nucleolonema / nucleolus / fibrillar centre / dense fibrillar component / rDNA

\section{Introduction}

In 1951 Estable and Sotelo [12], by light microscope observation of both animal and plant cells after silver impregnation described an intranucleolar filamentous structure that they termed "nucleolonema" on account of its morphology. They called the remaining part of the nucleolus pars amorpha. The permanence of some nucleolonematal parts throughout mitosis was postulated [13].

In electron microscopy, early works [2] showed that nucleoli frequently contain thin interconnected threadlike structures which were called nucleolonemata. They may be composed of either fibrillar or granular components or both, and thus are composed predominantly of ribonucleoprotein (Nucleolus Nomenclature Committee, Montevideo, 1966). More recent electron microscopic studies have led to the distinction between 2 main types of nucleoli in animal cells: the compact nucleolus and the reticulated nucleolus [54] (figs $1 \mathrm{~b}, \mathrm{c}$, and $2 \mathrm{~b}, \mathrm{c}$ ). These 2 types are made up of the same subcomponents as illustrated in figures $1 \mathrm{~b}, \mathrm{c}$ but their morphology is very different. In the latter, both the granular and fibrillar components form an anastomosed network which is designated by the term "nucleolonema". The more recent definition of the nucleolonema has been given by Jordan [28] who consider it as formed of threads and sheets, characteristically $0.1 \mu \mathrm{m}$ in diameter or thickness. These may be made up of either dense fibrillar component (DFC) or granular component (GC). This definition is quite valid as far as the animal cell reticulated nucleoli are concerned. In plant cells, however, only nucleoli of the compact type are described. In these nucleoli, a nucleolonema can appear, but it is somewhat different in electron microscopy from that of animal reticulated nucleoli $[10,32,36,43]$. Thus the aims of the present paper are: a) to compare the plant and animal nucleolonemata and to specify their ultrastructural differences; b) to propose a definition which better corresponds to the plant cell nucleolonema; and c) to propose a simple unambiguous terminology.
Is an intranucleolar filamentous structure frequently observed and is it a natural structure?

From the time of the discovery of the nucleolonema by Estable and Sotelo [12] until the present day, intranucleolar filamentous structures have been described by light microscopy (table I). These studies have established that in the nucleolus of both animal and plant cells one can observe filaments strongly resembling the nucleolonema. The estimated dimensions fluctuate from $5-55 \mu \mathrm{m}$ in length and 1.5-2 $\mu \mathrm{m}$ in thickness. Some authors have called these filaments nucleolonema but several other appellations have also been used : nucleolar loop, nucleolar track, nucleolar necklace, nucleolar strand, row (table I).

In most cases, however, the filamentous structure are detected in animal material (chick embryo cells or rat cells) only after drug application (adenosine or analogous, DRB) $[15,16,21,33,34,48]$, or the suppression of one element of the culture medium (arginine) [20], and in plant cells after the treatment of isolated nuclei with a detergent [30, 31]. For example, in phase contrast microscopy, one can observe that within 2 or $3 \mathrm{~min}$ of treatment of isolated nuclei with Tween-80, nucleoli of plant cells unfold into filamentous structures or nucleolonemata. Seed albumen is a favourable material for such a study; on the other hand, in meristematic root cells the nucleolonemata unfold less after detergent application [30]. Adenosine or detergents are likely to cause the loss of one or several nucleolar constituents (granular component, part of the matrix) and this permits the unfolding of the filament. Since the nucleolar filaments only appear after specific treatments, one could conclude that they are nothing but artefacts. However, Locke and Leung [35] have shown that in the epidermal cells of the Lepidoptera Calpodes, the nucleolar morphology is strongly modified in relation to the content of hemolymph ecdysteroid. They found that at the last larval stage, 3 ecdysteroid peaks are followed by nucleolar cycles. An intercycle nucleolus is compact; it unfolds under the influence of the hormone into a filament (nucleolar necklace) which can attain a length of 
$\approx 23 \mu \mathrm{m}$. At the end of the cycle, each filament contracts to again form a compact nucleolus. Godward [17] also observed such a structure in several untreated species of Spirogyra. By analyzing serial sections prepared for light microscopy in Allium porrum Lafontaine and Lord [32] observed an elaborate convoluted filamentous structure, the nucleolonema, which extends throughout the nucleolar mass.

From these observations, one can conclude that at the light microscope level, a filamentous nucleolar structure can exist, not infrequently in natural conditions, as already shown by Estable and Sotelo [12]. One can also assume that these intranucleolar filaments probably correspond to the nucleolonemata described by the same authors.

What is the ultrastructural morphology of the nucleolonema in animal and plant cells?

Numerous ultrastructural studies have established that a nucleolonema corresponding exactly to Jordan's definition is frequently observed in the reticulated nucleoli of several types of animal cells $[14,41,45,54]$ (figs $1 c$ and $2 c$ ).
In plant cells, for the majority of the authors, the nucleolonema appears as structurally somewhat different. For Chouinard [6] it consists of a meandering channel through which the relatively uncoiled nucleolus-organizing segment of the nucleolar chromosome passes. In cross or oblique sections, the channel appears as less electronopaque zones (lacunae, lacunar spaces) surrounded by dense fibrillar component. These light zones have been equated with the fibrillar centres (FCs) of animal cell nucleoli [18]. Later, Chouinard observed that the dense fibrillar component, associated with the chromatincontaining lacunar spaces, can be interrupted with the granular [7] or vacuolar [8] components. So these latter components can be directly in contact with the lacunar spaces or fibrillar centres. In maize, such interruptions have also been observed (Motte et al, unpublished).

Ultracytochemical studies on Allium porrum [32; see refs in 36] and on the alga Astasia longa [5] strongly suggest that the nucleolonema is a filament whose diameter fluctuates between $0.3-1.5 \mu \mathrm{m}$. In cross-sections, this filament axis appears as a lacunar space or fibrillar centre, frequently surrounded by an annular layer of dense fibrillar component. Ultrathin sections of the same
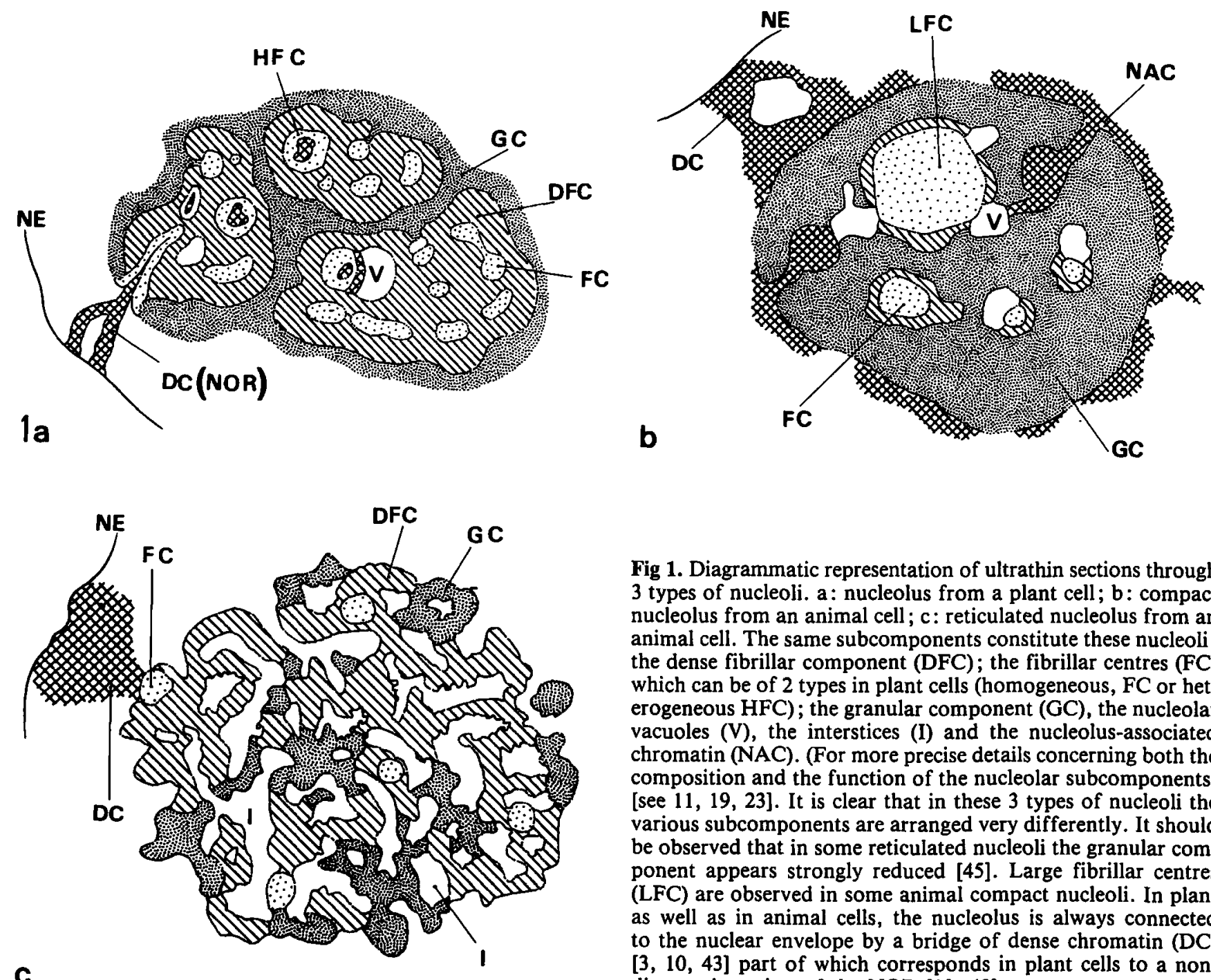

Fig 1. Diagrammatic representation of ultrathin sections through 3 types of nucleoli. a: nucleolus from a plant cell; $b$ : compact nucleolus from an animal cell; c: reticulated nucleolus from an animal cell. The same subcomponents constitute these nucleoli : the dense fibrillar component (DFC); the fibrillar centres (FC) which can be of 2 types in plant cells (homogeneous, FC or heterogeneous HFC); the granular component (GC), the nucleolar vacuoles (V), the interstices (I) and the nucleolus-associated chromatin (NAC). (For more precise details concerning both the composition and the function of the nucleolar subcomponents, [see 11, 19, 23]. It is clear that in these 3 types of nucleoli the various subcomponents are arranged very differently. It should be observed that in some reticulated nucleoli the granular component appears strongly reduced [45]. Large fibrillar centres (LFC) are observed in some animal compact nucleoli. In plant as well as in animal cells, the nucleolus is always connected to the nuclear envelope by a bridge of dense chromatin (DC) $[3,10,43]$ part of which corresponds in plant cells to a nondispersed portion of the NOR $[10,43]$. 
nucleolus, where such juxtaposed annular structures are visible, show many cross-sections through the folded nucleolonema. In appropriate preparations, some of the peripherally located lacunar spaces are found to be continuous with segments of chromosomes. For Lafontaine et al $[5,32,36]$, it is beyond doubt that the nucleolonema represents the main part of the fibrillar component of the nucleolus, Ashraf and Godward [1] have also suggested for another alga Spirogyra, that an axis composed of pale fibrillar material of fibrillar centres corresponds to the nucleolar chromatin surrounded by the dense fibrillar material. These investigations at the ultrastructural level suggest the presence of a complex filamentous structure within the plant cell nucleolus. However the ultimate proof of such a structure has to be demonstrated by 3-dimensional reconstructions. Three-D reconstructions from serial ultrathin sections have been carried out in the nucleolus of radicle cells of 2 higher plant embryos, Sinapis alba, a dicotyledon [10] and Zea mays, a monocotyledon [43], both at the quiescent stage and during early germination. Concurrently with the strong nucleolar activation accompanying early germination [9], each thread of dense intranucleolar chromatin of the quiescent cell is progressively transformed into a nucleolonema, the axis of which is formed by the fibrillar centres. The nucleolonema is ramified, each ramification starting from a hetero- geneous fibrillar centre $[11,43]$. The nucleolonema thus appears as an arborescent structure mainly composed of fibrillar component, anchored by its base to the interphasic NOR-bearing chromosome. Loops also characterize the nucleolonema $[29,43]$ (fig $2 a)$. Such a nucleolonema is very close to that proposed by Luck and Lafontaine in Allium [36]. It must be noted that it is entirely formed by both the dense fibrillar component and the fibrillar centres. Recently, Jordan [29], by 3-D reconstruction, established that in the nucleolus of Spirogyra also, all the fibrillar centres form a looped axis. In addition, it should be noted that in plant cells, the layer of dense fibrillar component surrounding the fibrillar centres is significantly thicker $( \pm 0.2-0.3 \mu \mathrm{m})$ than in animal cells [11]. However, in one plant species, Allium cepa, the fibrillar centres have been described as discrete entities [38]. Discrepancies concerning data on plant cells may be due to the fixative used.

Adequate fixation is an important factor in understanding the structure-function relationships of the nucleolus. Glutaraldehyde is an excellent fixative for proteins and is the most widely used substance for electron microscopy. However, several biochemical studies [4, 52, 53] have established that only formaldehyde crosslinks proteins to DNA. Moreover, Williams et al [57], working on pea root tips fixed solely in glutaraldehyde, pointed out that the fibrillar centres were difficult to distinguish. In comparing

Table I. Intranucleolar filamentous structures in the literature.

\begin{tabular}{|c|c|c|c|c|}
\hline Author(s) & Material & Appellation & $\begin{array}{l}\text { Dimensions }(\mu \mathrm{m}) \\
\text { Length } \times \text { thickness }\end{array}$ & Number/nucleolus \\
\hline Godward [17] & Spirogyra & Nucleolar track & $25 \times 2$ & - \\
\hline Estable \& Sotelo [12] & $\begin{array}{l}\text { Allium cepa } \\
\text { Animal cells }\end{array}$ & Nucleolonema & - & Several \\
\hline Lettre \& Siebs [33] & $\begin{array}{l}\text { Chick fibroblast } \\
\text { ( }+ \text { adenosine })\end{array}$ & $\begin{array}{l}\text { Nucleolonema } \\
\text { (Feulgen positive) }\end{array}$ & - & - \\
\hline Lacour [30] & $\begin{array}{l}\text { Scilla sibirica } \\
\text { Tulbaghia violacea } \\
(+ \text { Tween } 80)\end{array}$ & Nucleolonema & $35-55 \times 1.4$ & $3-6(3 n)$ \\
\hline Lettre, Siebs \& Paweletz [34] & $\begin{array}{l}\text { Chick fibroblast } \\
\text { ( }+ \text { adenosine })\end{array}$ & $\begin{array}{l}\text { Nucleolonema } \\
\text { (Associated-DNA) }\end{array}$ & - & - \\
\hline Lacour \& Wells [31] & $\begin{array}{l}\text { Ipheon uniflorum } \\
(+ \text { Tween } 80)\end{array}$ & Nucleolar loop & $20 \times 1.4$ & - \\
\hline Ghosh \& Lettre [15] & $\begin{array}{l}\text { Chick fibroblast } \\
\text { ( }+ \text { adenosine })\end{array}$ & $\begin{array}{l}\text { Nucleolonema } \\
\text { (Associated-DNA) }\end{array}$ & - & - \\
\hline Ghosh, Lettre \& Ghosh [16] & $\begin{array}{l}\text { Chick fibroblast } \\
\text { ( }+ \text { adenosine })\end{array}$ & $\begin{array}{l}\text { Nucleolonema (presence of } \\
\text { DNA, RNA, proteins }\end{array}$ & - & - \\
\hline Granick \& Granick [20] & $\begin{array}{l}\text { Chick myoblast } \\
\text { (- arginine) }\end{array}$ & Nucleolar necklace & $5-20 x-$ & - \\
\hline Granick [21] & $\begin{array}{l}\text { Chick fibroblast } \\
\text { ( }+ \text { adenosine })\end{array}$ & Nucleolar necklace & $20 x-$ & - \\
\hline Scheer et al [48] & Cultured rat cells & $\begin{array}{l}\text { Nucleolar necklace rows } \\
\text { (presence of RNA polymeraseI, } \\
\text { argyrophilic proteins) }\end{array}$ & $15-22 \times 0.4-0.6$ & Several \\
\hline Locke \& Leung [35] & Calpodes & Nucleolar necklace & $23 x-$ & $1-2$ \\
\hline Manuelidis [37] & $\begin{array}{l}\text { Human glioma cell } \\
\text { lines }\end{array}$ & Nucleolar strands & $-\times 0.2$ & - \\
\hline
\end{tabular}


the nucleoli of maize treated with several fixatives, Motte et al [43] established by a quantitative study that it is the paraformaldehyde fixation which better preserves the fibrillar centres. Thus, in 3-D reconstructions of the plant cell nucleolus, it is essential to use this mode of fixation to more fully understand the spatial organization of these structures. The above results show that the plant cell nucleolonema is structurally different from that in animal cells. It is exclusively formed by the fibrillar component, including the fibrillar centres, while in the reticulated nucleoli of animal cells it is formed by the DFC and the granular component with the exclusion of the fibrillar centres.

It should be observed that in some plant nucleoli, numerous small interstices are scattered within the granular component which in consequence appears as a narrowmesh net whose spatial relationships with the dense fibrillar component are not clearly visible [26, 27]. This network is very different from the threads of granular component that form a part of the nucleolonema. These are clearly in continuity and have the same dimensions as the threads of dense fibrillar component (fig 1c).

What is the molecular composition and organization of the nucleolonema?

If the data concerning the nucleoli that display a nucleolonema are exclusively considered, these are still insufficient to provide a functional molecular mapping of this structure. Data are more abundant for animal cells.

\section{Animal cells}

Early cytochemical studies based on light microscopy techniques showed the presence of DNA within the nucleolonema several times, either by the Feulgen reaction $[33,34]$ or by autoradiography $[15,16]$. The localization of DNA by the Feulgen reaction remained controversial [34]. The presence of RNA and proteins has also been established by light microscopy [see refs in table I]. From these observations some authors have already concluded that the nucleolonema has a core of DNA around which RNA and protein have accumulated. More recently, Scheer et al [48] have observed after a DRB treatment of cultured rat cells, the formation of several nucleolar necklaces devoid of preribosomal particles and containing several (up to 30) granules of $0.4-0.6 \mu \mathrm{m}$ in diameter. Some of these necklaces could attain $15-22 \mu \mathrm{m}$ in length and usually 6 were found per nucleus, corresponding to the 6 separate nucleolar organizer regions. The necklace granules were positive for RNA polymerase I and argyrophilic proteins. In human glioma cells, a ribosomal DNA probe showed that in interphase nucleoli, ribosomal cistrons formed strands $\pm 0.2 \mu \mathrm{m}$ in thickness that traversed the nucleolus [37]. Investigations in EM cytochemistry $[14,45]$ have established that the fibrillar parts of the nucleolonema are composed of argyrophilic proteins, pre-rRNPs and DNA. This composition suggests that it is in a highly active state in synthesizing ribosomal RNA.

\section{Plant cells}

From high resolution autoradiography and ammineosmium methods it appears that DNA is present in both fibrillar centres and dense fibrillar component [32; see refs in 47 , Motte et al, in preparation] and that the site of rDNA transcription is the dense fibrillar component [see refs in 11]. Recently however, Scheer et al $[49,50]$, using immunoelectron microscopy, and Thiry [56], using in situ hybridization have suggested that in animal nucleoli the rDNA is located exclusively in the fibrillar centres. Recently Raska et al [46] have observed, with specific antiserum, that RNA polymerase I is localized mainly in the fibrillar centres but is also present in the DFC. In our opinion EM observations using antibodies against nucleolar antigen or rDNA probes should be viewed with reserve. Indeed, the quantity of transcriptionally active rDNA is probably low within an ultrathin section through the dense fibrillar component and could fall under the detection threshold of these cytochemical methods which probably only reveal the molecules near the section surface. In plant cells, data from such techniques have not yet been published. Motte et al (unpublished) and Medina [40] have found, using anti-DNA antibody, that DNA is present in both the nucleolonematal axis and the surrounding dense fibrillar component. Argyrophilic proteins are either present exclusively in the DFC $[42,44]$ or in both the DFC and FCs [39]. Using the available molecular data Deltour and Mosen [11] recently proposed a hypothetical model for the macromolecular organization of the plant cell nucleolus. In this model, the active ribosomal genes are localized in the dense fibrillar component, while the non-transcribed spacers are localized in the fibrillar centres. A very similar arrangement has been proposed by Schwarzacher et al [51] for the animal cell nucleolus.

What are the ultrastructural and molecular differences between plant and animal nucleolonemata?

The following differences can be underlined:

- In plant cells, the relatively continuous nucleolonematal axis is constituted by both the homogeneous and heterogeneous fibrillar centres (or lacunae) whilst in animal cells, the nucleolonematal threads, or sheets, are associated with few discrte fibrillar centres [14] or without any [45] (figs $1 a, b, c$ and $2 a, b, c)$. In animal cells the fibrillar centres are not considered as an nucleolonematal constituent [28].

- The plant cell nucleolonema is constituted almost exclusively of the fibrillar component (CFs and DFC) when the threads or sheets of the animal cell nucleolonema are made up of dense fibrillar and/or granular components [28] (figs $1 \mathrm{c}$ and 2b, c).

- The nucleolonema of a plant cell is significantly thicker than the nucleolonematal threads of an animal cell (compare figs $1 \mathrm{a}$ and $\mathrm{lb}$ ). This is mainly due to the dense fibrillar component, which is more important in plant cells.

- In plant cell nucleolonema, the active ribosomal genes are probably localized within the dense fibrillar component.

\section{Definition suggested for the plant cell nucleolonema}

Taking into account these differences, we suggest the following definition for the higher plant cell nucleolonema. The nucleolonema is an intranucleolar ramified filament of several $\mu \mathrm{m}$ in length, which can display loops. Is is made up of a more or less continuous axis, resulting from the 
juxtaposition of all the homogeneous and heterogeneous fibrillar centres, and of an external layer of dense fibrillar component, which contains active rDNA (ribosomal genes in transcription), rRNA and argyrophilic protein (fig 2a). This layer is interrupted locally by the granular or vacuolar components. The nucleolonema is fixed by its base to the interphasic NOR-bearing chromosome of which it is a lateral extension [11]. Several nucleolonema ta can be present in one and the same nucleolus, each of them corresponding to one NOR. The nucleolonema contains both the active and inactive (in the form of heterogeneous FCs) rDNA of an interphasic active nucleolus. The compact nucleolus of the plant cell appears to be formed by one or several strongly folded sticky nucleolonemata included within the granular component. They could have some relationship with the nucleolar skeleton. The nucleolonema is the counterpart of the metaphasic nucleolus-organizing region (NOR).

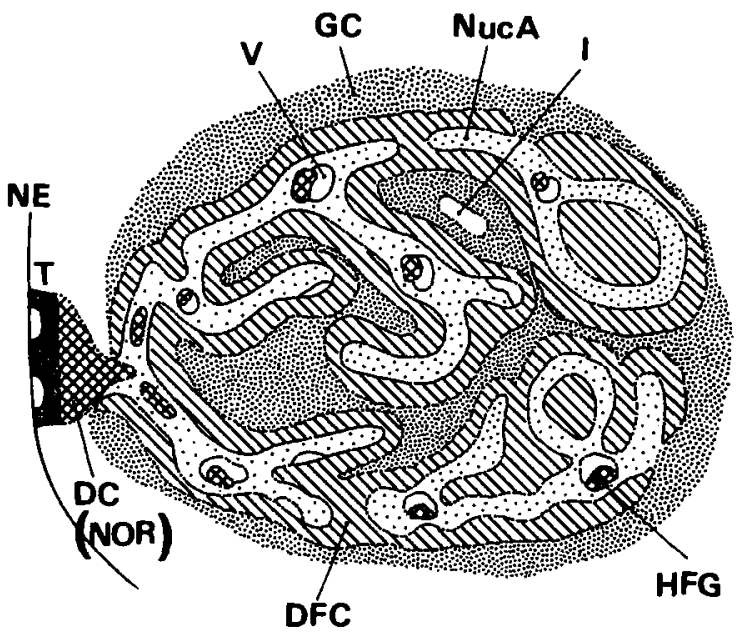

$2 \mathbf{a}$

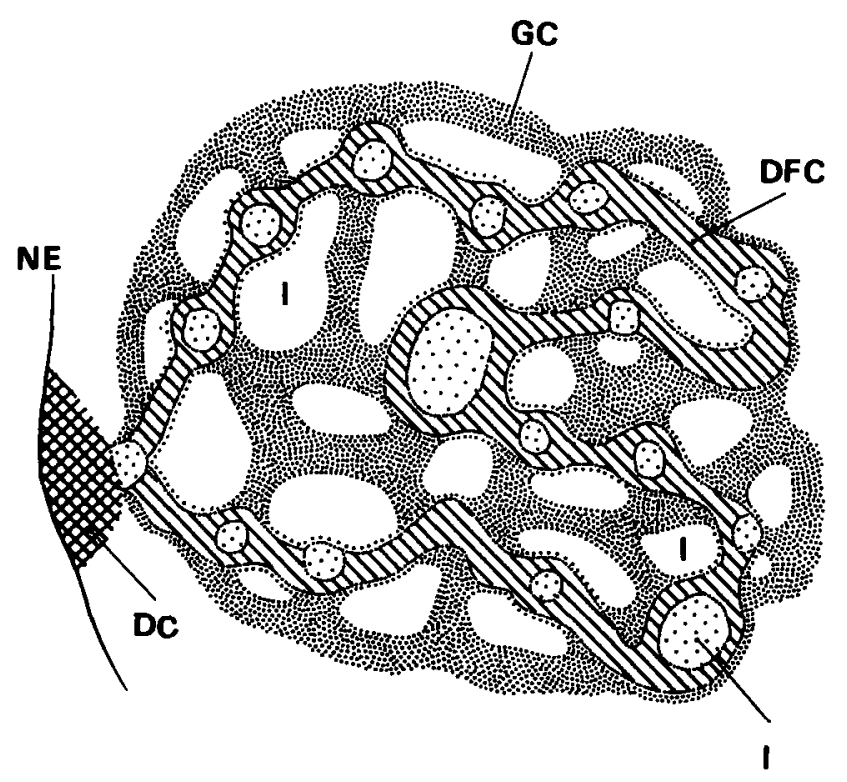

C

\section{Outstanding questions}

An answer to the following questions would specify the exact structural and molecular differences between plant and animal cell nucleolonema:

- Are there structural and molecular differences between the fibrillar centres of animal cells and the corresponding structures (lacunae, lacunar spaces, pale fibrillar material) in plant cells? With regard to this, recently Motte et al [44] and Moreno et al [42] have shown that the plant cell fibrillar centres do not contain argyrophilic proteins like those of animal cells.

- Why is the dense fibrillar component of plant cells more abundant? Is it because more ribosomal genes are simultaneously active in those cells that are known to generally contain a higher number of copies of these genes? From data in the literature concerning the number of ribosomes per cell, their turnover and the velocity of

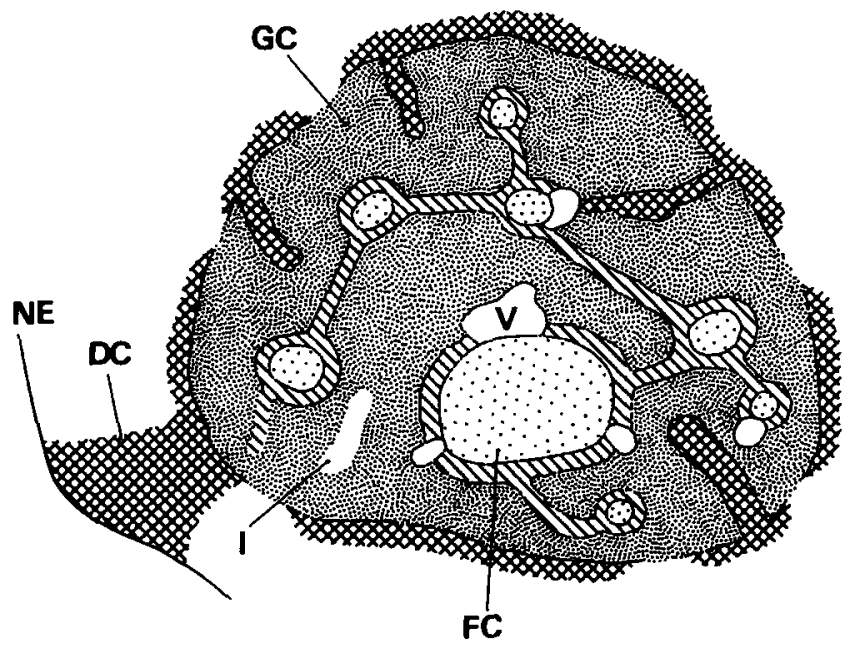

b

Fig 2. Diagrammatic 3-dimensional reconstructions of the different types of nucleoli shown in figure 1. a: Nucleolus from a plant cell; b: compact nucleolus from an animal cell; $c$ : reticulated nucleolus from an animal cell. The nucleolar subcomponents are represented by the same abbreviations as in figure 1 . Nuc A : nucleolonematal axis; $T$ : telomeric region of the NORbearing chromosome. A more or less continuous filamentous structure, the nucleolonema is present within the 3 types of nucleoli. This filament is composed of both DFC and FCs. 
ribosomal transcription [25; see refs in 22] one can calculate that 500-5000 genes could be simultaneously active in a single plant cell nucleolus. This is probably far more than in animal cell nucleolus.

- Does a nucleolonema also exist in compact nucleoli of animal cells, but in another form? Since the general belief is that each eukaryotic chromosome is made up of a single giant DNA molecule, the interphasic NOR is probably a large loop of this molecule, where the ribosomal genes are clustered. It is thus consistent to consider that this rDNA could link together the discrete fibrillar centres like beads on a string (fig $2 \mathrm{~b}$ ). In PK cells, Hozak et al [24] and in HEp-2 cells Thiry et al [55] have shown that a strand of dense fibrillar component connects the fibrillar centres together. Thus, in compact type animal cell nucleoli, a filamentous structure constituted of fibrillar component, possibly corresponding to the plant cell nucleolonema but structurally different (the fibrillar centres are discrete entities), can also be observed.

- What exactly is the role of the nucleolar vacuoles that are frequently seen in direct contact with the nucleolonematal axis inside the dense fibrillar component interruptions? (figs $1 \mathrm{a}, \mathrm{b} ; 2 \mathrm{a}, \mathrm{b}$ ). Several authors $[8,10$, 43] have shown that some kind of nucleolar vacuoles, the nucleolar chromatin dispersal vacuoles (NCDV) contain DNA and have suggested that they can play a role in the dispersion of this DNA. Thiry [56] has shown that the fibrillar centre-associated nucleolar vacuoles contain DNA and can be the site of this DNA condensation after an actinomycin $\mathrm{D}$ treatment. Preliminary results in our laboratory also suggest that small vacuoles are associated with the fibrillar centres when they change from their homogeneous to their heterogeneous form.

- An already well established morphological difference is the almost constant presence, in compact nucleoli of animal cells, of a shell of dense perinucleolar chromatin which projects finger-like extensions deeply within the nucleolus (figs $1 \mathrm{~b}$ and $2 \mathrm{~b}$ ). Thus 2 types of DNA are simultaneously present in these nucleoli. In plant cells, such an external nucleolus-associated chromatin is generally absent and consequently the intranucleolar DNA is most probably only rDNA (figs $1 \mathrm{a}$ and $1 \mathrm{~b}$ ). What is the respective role of the 2 types of DNA present in the animal cell nucleolus? Recently Vasquez-Nin et al [40] have shown, by in situ hybridization, that, in animal cells, the U3-snRNA genes are localized in the interphasic nucleolus but not in the NOR at the metaphase.

\section{Conclusion and proposal for a terminology}

We have shown that in spite of the apparent likeness between the plant and the compact animal nucleolus, there are ultrastructural differences that are worthy of note (compare figs $1 a$ and $2 b$ with figs $2 a$ and $2 b$ ). Thus, the plant cell nucleolus is not an exact replica of that of the animal cell. In the future, it should be interesting to determine to what extent these ultrastructural differences are also found at the molecular level.

It would be easier for both the interphasic plant or animal nucleolus to designate by the term nucleolonema* the whole fibrillar component (DFC and FCs) because it contains most of the intranucleolar DNA. However, the difficulty to put this proposal into practice is illustrated by the habit of zoologists to call nucleolonema a structure which also contains some granular component. To avoid any confusion, we thus suggest that each time it should be mentioned if it is a plant or an animal nucleolonema which is under question. In the latter instance, the type of the nucleolus (compact or reticulated) should also be mentioned

\section{Acknowledgments}

The authors thank Mrs M Dejace for help in preparing the manuscript and $Y$ Lemoine for providing the diagrams. This work was supported by grants from the FRFC (Nos 2.405.87 and 2.4521.89) and from the Belgian Government through the programme of Action de Recherche Concertée de l'Etat Belge (No 88/93-129).

\section{References}

1 Ashraf M, Godward MBE (1980) The nucleolus in telophase, interphase and prophase. $J$ Cell Sci 41, 321-329

2 Bernhard W (1966) Ultrastructural aspects of the normal and pathological nucleolus in mammalian cells. Natl Cancer Inst Monogr 23, 13-38

3 Bourgeois CA, Hubert J (1988) Spatial relationship between the nucleolus and the nuclear envelope: structural aspects and functional significance. Int Rev Cytol 111, 1-52

4 Brutlag D, Schlehuber C, Bonner J (1969) Properties of formaldehyde-treated nucleohistone. Biochemistry 8 , $3214-3218$

5 Chaly N, Lord A, Lafontaine JG (1979) Nucleolar organization in the euglenoid Astasia longa as disclosed by selective staining, actinomycin D treatment, and cold shock. Can $J$ Bot 57, 2031-2043

6 Chouinard LA (1975) An electron-microscope study of the intranucleolar chromatin during nucleologenesis in root meristematic cells of Allium cepa. J Cell Sci 19, 85-101

7 Chouinard LA (1981) Ultrastructural association of the chromatin-containing lacunar spaces with the granular component of the interphase nucleolus in Allium cepa. Can $J$ Bot 59, 2073-2076

8 Chouinard LA (1982) Ultrastructural association of the chromatin-containing lacunar spaces with the vacuolar component of the interphase nucleolus in Allium cepa. Can $J$ bot $60,2624-2628$

9 Deltour R (1985) Nuclear activation during early germination of the higher plant embryo. $J$ Cell Sci 75, 43-83

10 Deltour R, Mosen H, Bronchart R (1986) Three-dimensional electron microscopy of the internal nucleolus-associated chromatin and of the nucleolar vacuoles during early germination of Sinapis alba. J Cell Sci 82, 53-71

11 Deltour R, Mosen H (1987) Proposals for the macromolecular organization of the higher plant nucleolonema. Biol Cell $60,75-86$

12 Estable C, Sotelo JR (1951) Una nueva estructura celular: el nucleolonema. Publ Invest Cient Biol (Montevideo) 1, 105-126

13 Estable C (1966) Morphology, structure, and dynamics of the nucleolonema. Natl Cancer Int Monogr 23, 91-105

14 Franke W, Scheer $U$, Spring $H$, Trendelenburg MF, Zentgraf H (1979) Organization of nucleolar chromatin. In: The Cell Nucleusy vol VII, (Busch H, ed) Academic Press Inc, New York, London, pp 49-95

15 Ghosh S, Lettre R (1969) Demonstration of DNA synthesis in filamentous structure of the nucleolus. Naturwissenschaften 56,140

16 Ghosh S, Lettre R, Ghosh I (1969) On the composition of the nucleolus with special reference to its filamentous structure. Z Zellforsch 101, 254-265

17 Godward MBE (1950) On the nucleolus and nucleolarorganizing chromosomes of Spirogyra. Ann Bot 14, 39-55

18 Goessens G, Lepoint A (1979) The nucleolus-organizing regions (NORs): recent data and hypotheses. Biol Cell 35, 211-220 
19 Goessens G (1984) Nucleolar structure. Int Rev Cytol 87, $107-158$

20 Granick S, Granick D (1971) Nucleolar necklaces in chick embryo myoblasts formed by lack of arginine. J Cell Biol $51,636-642$

21 Granick D (1975) Nucleolar necklaces in chick embryo fibroblast cells. II. Microscope observations of the effect of adenosine analogues on nucleolar necklace formation. $J$ Cell Biol. 65, 418-427

22 Gunning BES, Steer MW (1975) Ultrastructure and the Biology of Plant Cells. Edward Arnold, London, p 48

23 Hernandez-Verdun D (1986) Structural organization of the nucleolus in mammalian cells. Methods Achi Exp Pathol 12, 26-62

24 Hozak P, Zatsepina O, Vasilyeva I, Chentson Y (1986) An electron microscopic study of nucleolus-organizing regions at some stages of the cell cycle (G0 period, G2 period, mitosis). Biol Cell 57, 197-206

25 Jackson PJ, Lark KG (1982) Ribosomal RNA synthesis in soybean suspension cultures growing in different media. Plant Physiol 69, 234-239

26 Jordan EG, Godward MBE (1969) Some observations on the nucleolus in Spirogyra. J Cell Sci 4, 3-15

27 Jordan EG, Chapman JM (1971) Ultrastructural changes in the nucleoli of Jerusalem artichoke (Helianthus tuberosus) tuber discs. J Expt Bot 22, 627-634

28 Jordan EG (1984) Nucleolar nomenclature. J Cell Sci 67, $217-220$

29 Jordan EG (1987) Nucleolar organizers in plants. In: Chromosomes Today, vol 9 (Stahl A, Luciani JM, VagnerCapodano AM, eds) Allen and Unwin, London, pp 272-283

30 La Cour LF (1966) The internal structure of nucleoli. In: Chromosomes Today, vol I (Darlington CD, Lewis KP, eds) Oliver and Boyd, Edinburgh-London, pp 150-160

31 La Cour LF, Wells B (1967) The loops and ultrastructure of the nucleolus of Ipheon uniflorum. Z Zellforsch Mikrosk Anat 82, 25-45

32 Lafontaine JG, Lord A (1973) An ultrastructural and radioautographic investigation of the nucleolonematal component of plant interphase nucleoli. J Cell Sci 12,369-383

33 Lettre R, Siebs W (1954) Zur Struktur des Nucleolus. Naturwissenschaften 41,458

34 Lettre R, Siebs W, Paweletz N (1966) Morphological observations on the nucleolus of cells in tissue culture with special regard to its composition. Natl Cancer Inst Monogr 23, $107-123$

35 Locke M, Leung H (1985) Nucleolar necklace formation in response to hemolymph ecdysteroid peaks. Tissue \& Cell 17 (4), 589-603

36 Luck BT, Lafontaine JG (1980) An ultracytochemical study of nucleolar organization in meristematic plant cells (Allium porrum). $J$ Cell Sci 43, 37-58

37 Manuelidis L (1985) Indications of centromere movement during interphase and differentiation. Ann NY Acad Sci 450, 205-221

38 Medina FJ, Risueño MC, Moreno Díaz de la Espina S (1983) 3-D reconstruction and morphometry of fibrillar centres in plant cells in relation to nucleolar activity. Biol Cell 48 , 31-38

39 Medina FJ, Risueño MC, Sánchez-Pina MM, FernándezGómez ME (1983) A study on nucleolar silver staining in plant cells. The role of argyrophilic proteins in nucleolar physiology. Chromosoma 88, 149-155

40 Medina FJ (1989) Meeting report. The nucleolus, in the spotlight. Eur J Cell Biol (in press)
41 Mirre C, Knibiehler B (1982) A re-evaluation of the relationship between the fibrillar centres and the nucleolusorganizing regions in reticulated nucleoli: ultrastructural organization, number and distribution of the fibrillar centres in the nucleolus of the mouse sertoli cell. $J$ Cell Sci 55 , 247-259

42 Moreno FJ, Rodrigo RM, Gracia-Navarro F, GarciaHerdugo G (1989) Nucleolar component behaviour in plant cells under different physiological conditions. A morphological, cytochemical and quantitative study. Biol Cell $65,67-74$

43 Motte P, Deltour R, Mosen H, Bronchart R (1988) Threedimensional electron microscopy of the nucleolus and nucleolus-associated chromatin (NAC) during early germination of Zea mays L. Biol Cell 62, 65-81

44 Motte P, Mosen H, Bronchart R, Deltour R (1988) Ultrastructural localization of argyrophilic proteins in nucleoli of Zea mays by two silver staining techniques. Biol Cell 64, 97-100

45 Ploton D, Bendayan M, Adnet JJ (1983) Ultrastructural localisation of Ag-NOR proteins and nucleic acids in reticulated nucleoli. Biol Cell 49, 29-34

46 Raska I, Reimer G, Jarnik M, Kostrouch Z, Raska K Jr (1989) Does the synthesis of ribosomal RNA take place within nucleolar fibrillar centers or dense fibrillar components? Biol Cell 65, 79-82

47 Risueño MC, Medina FJ (1986) The nucleolar structure in plant cells. Revisiones Sobre Biologia Celular 7, 1-143

48 Scheer U, Hugle B, Hazan R, Rose KM (1984) Drug-induced dispersal of transcribed rRNA genes and transcriptional products: immunolocalization and silver staining of different nucleolar components in rat cells treated with 5, 6-dichloro$\beta$-D-ribofuranoxylbenzimidazole. $J$ Cell Biol 99, 672-679

49 Scheer U, Rose KM (1984) Localization of RNA polymerase I in interphasic cells and mitotic chromosomes by light and electron microscopic immunocytochemistry. Proc Natl Acad Sci USA 81, 14531-1435

50 Scheer U, Raska I (1987) Immunocytochemical localization of RNA polymerase $I$ in the fibrillar centers of nucleoli.In: Chromosomes Today, vol 9 (Stahl A, Luciani JM, VagnerCapodano AM, eds) Allen and Unwin, London, pp 284-294

S1 Schwarzacher HG, Wachtler F (1987) Nucleolus organizer regions and nucleoli : cytological findings. In: Chromosomes Today, vol 9 (Stahl A, Luciani JM, Vagner-Capodano AM, eds) Allen and Unwin, London, pp 252-260

52 Sewell BT, Bouloukos C, Von Holt C (1984) Formaldehyde and glutaraldehyde in the fixation of chromatin for electron microscopy. J Microsc 136, 103-112

53 Siomin YA, Simonov VV, Poverenny AM (1973) The reaction of formaldehyde with deoxynucleotides and DNA in the presence of amino acids and lysine-rich histone. Biochem Biophys Acta 331, 27-32

54 Stahl A (1982) The nucleolus and nucleolar chromosomes. In: The Nucleolus (Jordan EG, Cullis CA, eds) Cambridge University Press, Cambridge, pp 1-24

55 Thiry M, Goessens G (1986) Ultrastructural study of the relationship between the various nucleolar components in Ehrlich tumour and HEp-2 cell nucleoli after acetylation. Expt Cell Res 164, 232-242

56 Thiry M (1989) Organisation ultrastructurale du nucléole au cours du cycle cellulaire. Unpublished thesis, University of Liège

57 Williams SM, Charest PM, Lafontaine JG (1985) Nucleasegold and protease-gold labelling over the nucleolar vacuoles of pea root tip cells. Biol Cell 55, 21-26 